\title{
PAULINE INSPIRATIONS FOR THE STUDY OF IGBO DEITIES
}

\author{
Jude C. Obidigbo
}

\section{Introduction}

Since its inception in 1974/ 77, the need for African theology is growing by the day. Theologians on their part have also proved their readiness to delve into this all important field. However, the journey so far has taken a one-sided approach as most theologians always begin from their Christian background. The result is that even when they present coherent studies, the very Africans for whom they are meant find it difficult to accept and adopt them mostly for the obvious reason that they neglect the most fundamental aspects of their traditional religion and culture.

This paper is part of our series intended to bridge some of these gaps with the study of the Igbo deities. It studies African theology from the African background and deals with one of the most fundamental aspects of African Traditional Religion. For "belief in and cult of the deities constitute one of the intractable problems in the studies of African Traditional Religion, and the theologicopastoral attempts to incarnate Christianity in African world views" ( Metuh 1996: 109).

This work is also facilitated by the evident similarities between the Igbo and Christian worldviews and takes St. Paul's experiences and letters as guide. This presupposes that such beliefs in deities and their influences were also prevalent among some of those St. Paul ministered to. It further takes cognizance of the fact that Igbo is among the African tribes with belief in non-human deities. Yet, it seems that neither the classical notion of deity, nor St. Paul makes any such distinctions.

\section{Clarification of Terms}

We shall now attempt the explication of such terms as Deity, God/ Gods, and Idols as found in the Pauline narratives.

\section{Deity}

The word deity refers to "the essential nature of being a god or divinity" (answers.com, 10 ${ }^{\text {th }}$ September, 2009). In this case it can go 
for God as the Deity or gods/ goddesses (unlike in African Traditional Religion where the name is restricted to the non-human spirits just below the Supreme Being in the hierarchy). This is so because it is derived from the same Latin deus (god) and dea (goddess) and other Indo European roots like the Sanskrit deva (god) and devi (goddess) and divya (transcendental, spiritual). Thus:

In the English language, the common noun god is equivalent to deity while the pronoun God (capitalized) references the unique deity of monotheism. Pantheism considers the universal itself to be a deity. Dualism is the view that there are two deities: a deity of good who is opposed and thwarted by a deity of evil, of equal power. (Answers.com, 10 ${ }^{\text {th }}$ September, 2009).

The Wikipedia Free Encyclopedia (2009) however further defines the deity as "a postulated preternatural or supernatural immortal being who may be thought of as holy, divine, or sacred, held in high regard, and respected by human beings".

\section{Gods/ Goddesses}

Apart from the GOD of the monotheistic religions and their manifestations therefore, the word god/ goddess refers to any one of the following:

- A supernatural being with such powers and attributes believed in and most times worshipped by a people and believed/ thought to control some parts of nature.

- An image of such a being

- Anything that is worshipped, idealized or followed.

- A very handsome man or woman

- A powerful ruler or despot.

While a general understanding of Deity includes God and gods/ goddesses, we are restricting our study to the first three outlined above. In them St. Paul's idea and Igbo Traditional Religion largely coincide especially as the Igbo experience does not largely support 
the idea of Deities as human beings, even when they are suspected to be humanly manipulated.

\section{Idols}

Worthy of mention is St. Paul's use of the word Idol (Gk. Eidolon) which simply means Image. This word first took a religious meaning or connotation with the Greek translation of the Hebrew Bible (the Septuagint) to refer among other things, to the physical representation of the Deities. Thus the idols in St. Paul have been described as the "non-Israelite or non-Jewish divinities considered to be false or alien gods. These are the gods of other nations from whom the Israelites are commanded to separate themselves" (answers.com, $11^{\text {th }}$ September, 2009). For Farlex (2009), they are material objects, especially carved images that are worshipped as gods / goddesses. For Christianity and Judaism therefore, any being (other than the one God) to which divine honour is paid, can be called an Idol.

With St. Paul therefore we are looking at those non-human/ disembodied spirits (gods and goddesses) believed in by various peoples and cultures and whose physical representations are often worshipped as Idols. These seem to have their types in Igbo religious experiences which we now see.

\section{Nature and Place of the Deities in Igbo Cosmology}

Like in most known cultures of the world, the deities form part and parcel of Igbo cosmology which according to Ifesieh (1989) refers to the body of beliefs about the universe which are common among members of the Igbo society and existentially demonstrated in their value system and attitudinal orientations.

Madu (1996) and Metuh (1987) succinctly describe this cosmology as comprising of two basic worlds- the visible and invisible worlds, with the invisible world subdivided into two- the world of God and the gods; situated somewhere above the firmament, and the underworld; somewhere beneath earth surface and the home of the ancestors, and disembodied spirits. The visible world on the other hand is populated by men and all material surroundings familiar to him- the sky, earth, rivers, forests, mountains and so forth. However, since these worlds are not 
mutually exclusive all the beings in the various spheres can and do easily cohere and interact.

The Igbo pantheon therefore has a hierarchy of beings in its retinue. At the head of the hierarchy is 'Chi-ukwu' (the Supreme Being) who is regarded as the creator and sustainer of the universe. Hence they call him 'Onye okike' (One who creates) and 'Onye nwe/ ji uwa' (One who owns /holds or sustains the world). However since this Being is quite removed from the created world, he left the world to the watchful eyes of the Deities.

The Deities are believed to be next in rank to the Supreme Being. Though they are generally believed to be created by the Supreme Being and subordinate to him, Igbo myths surrounding the nature and worship of God, and the fall of man have given rise to three theories concerning their relationship to the Supreme Being. Anyanwu (1999) opines that for those who hold that the Supreme Being is a Deus Otiosus, God has completely left the universe in the hands of the deities who then act independently but for God and are considered to be generally beyond human reproof. Proponents of animism on the other hand hold that God is to the deities only a primus inter pares. The most accepted position is however that the deities play a mediatory role between God and men or the rest of the world. In this case, the deities are God's servants or messengers/ angels in the world (to use the Judeo-Christian terminology).

Regardless of whichever opinion particular group hold, Igbo deities are also generally believed to be many and are classified loosely as major and minor deities. Major divinities are said to be universal or acknowledged within such a wide social group as the tribe or nation. These include; Anyanwu - represented by the Sun; Ala - represented by Earth; Igwe - represented by the Thunder; Ahiajoku - which is the Lord of Agriculture, Muo mmiri - a divinely appointed temptress; and Agwu-Nsi - the Lord of divination and healing. The Minor deities on the other hand, are those with whom the destiny of particular localities are associated and which occupy influential positions in those societies and have their shrines in them. Metuh (1999) gives such names as Eze Mewi, Ogwugwu, Idemili, Ulasi, Ubu, Ele, Ojiyi, Akpu, Ojukwu, Ngwu etc. It goes without saying that most of these deities are personifications of natural phenomena or their derivatives, hence the name Nature deities. To 
this extent they can also be manipulated by those who know their secrets.

However, it is good to point out that there is no strict agreement among scholars in the classification of these deities or in their gradations. In the thinking of the researcher, reasons for this can be sought in the segmented Igbo societies and their particular experiences or histories. Thus it appears that apart from the first three major deities mentioned above, the rest are not always regarded as such. Even scholars who recognize all five do not grade them in the same order. Arazu (2005) for instance argues for the supremacy of Ana even over God for what can be described as purely utilitarian motives. On this issue, therefore, Anyanwu (1999) writes that:

The differentiation between the major and minor divinities is as a result of modern scholars' attempt to build among the Igbo pantheon something like the Christian concept. In the traditional setting as is evident, one cannot say strictly that one divinity is major and the other minor. Individual communities and culture areas have their own ranking based on their environment. It means that what is a major divinity in one area could be termed minor in another area (p. 99).

\section{Pauline Approaches to the Study of the Deities}

We have to recall that with Israel's avowed monotheism, the Christian doctrine at its inception only saw the need to affirm a new dimension of this monotheism in the person of Jesus Christ. In other words, the Christian doctrine did not set out to convert the Jews to the one God but to explain the fact that Jesus was the Christ (Son of God and Messiah). As difficult as this task proved, the encounters with other predominantly non-Jewish populations proved more challenging since they necessitated the all-important task of first establishing the belief in ONE GOD before speaking of Christ as the one Messiah and mediator between God and man. This was the great intercultural attempt of the early church to which St. Paul (apostle of the gentiles), fully devoted himself. 
We shall here look at some instances of these in order to find valuable paradigms for the much vaunted Inculturation today.

1Cor.8: 1ff; 1Cor. 10:14- 33: Here Paul treated food offered to false gods in a community well known for such religious rites and rituals. About this community Fernand (1964) says that:

Almost anything could be said or thought about the immortal gods, provided the religious usages of the nation or the city were observed. When the victims were not consumed on the spot in the outer buildings of the temple or in the sacred grove, they served for a family banquet or were distributed to near relatives or even sold at a very low price to retailers (p.115).

Another commentator observes that generally, "meat was available in the ancient world only after great festivals when the priests sold the surplus of the meat of sacrificial victims that was their share" (Murphy-O'Connor, 2001, p. 806). This was the situation in which the Corinthian Christians (who were in the minority) found themselves.

The situation was further compounded by the existing divide between the so- called strong who maintained that idols are nothing as well as anything offered to them, and the weak who would immediately be appalled by the mere mention of idols not to talk of eating anything offered to them. Thus the situation was tense and the question complex as to necessitate Paul's complex and contextual explanations thus:

The so called Gods do not really exist or do not have independent existence since "there is no God other than the One" (1Cor. 8: 4 [New Jerusalem Bible: NJB]), "the Father from whom all things come and for whom we exist, and one Lord, Jesus Christ, through whom all things come and through whom we exist" (1Cor.8: 6 [NJB]). 
However for the sake of one's weak brothers and sisters who do not possess such knowledge, a Christian should refrain from any association with things pertaining to the idols so as not to scandalise them. Thus "if food can be the cause of a brother's downfall, I will never eat meat any more, rather than cause my brother's downfall" (1Cor.8: 13 [NJB]). Paul would further advise that no food should be eaten which is purposefully "sacrificed to demons who are not God" (1 Cor. 10: 20 [NJB]).

Acts 17: 16ff: More than in Corinth, Paul could be said to have met a rather hostile religion and culture in Athens. This is the setting of Acts. 17: 16ff for he did not spend a day in Athens before "his whole soul was revolted at the sight of a city given over to idolatry" (Acts 17: 16 [NJB]). His burning desire for the Gospel later led him to the Areopagus where he tried to combat paganism with secular wisdom, more because of the presence of shades of philosophers there.

The significance of Paul's preaching at the Areopagus is not sought in its success which is considered very minimal on some grounds, but more for its very attempts at incarnating Christianity from the people's background. Thus, in spite of what Paul thought about their frivolous idols:

- He first piqued their interest and curiosity by first of all recognizing their deep religiosity.

- From the sight of the Altar dedicated to an unknown God, he tried to lead them to acknowledge the God who made the universe and therefore cannot be contained in any shrine made by human hands.

- Finally Paul used a quotation from their own poet "to highlight the absurdity of their idolatry" (NJB Commentary).

Romans 1: 18-32: The possibility of reaching knowledge of God from various backgrounds is further buttressed by Paul in His letter to the Romans 1: 18-32. Here as in Gal. 4:8-9 Paul says among other things that:

- God had revealed himself in the Natural Order He created which every group of people or organized culture seem to be aware of. 
- The error of gentiles is that they preferred to worship these creatures and their images instead of the God who created them.

- Such idolatry therefore leads idolaters to bondage; enslaving them to their passions in various forms. In the words of Fitzmayer (2001), "Paul seeks to establish an intrinsic relation between sin and punishment; impiety brings its own retribution. Idolatry, the consequence of failure to honor God duly, is the source of immorality, for it is the 'big lie', (p. 836).

Acts. 14: 8-18: This is the setting at Lystra for an attempt at idolizing Paul and Barnabas after healing a cripple. Besides resisting this attempt, these disciples used the opportunity to denounce idolatory and to teach that God while remaining transcendent, can work with other instruments and in the natural order. Finally, by stopping the people from offering them sacrifices, Paul suggests that all honour and adoration should be given to God and not to these instruments.

\section{Merits of the Pauline Approaches}

From Paul's treatment of the deities just outlined, one can deduce the following:

1. St. Paul (though a Christian theologian) was convinced of the universal knowledge of God as manifested in the Natural Order and the rationally possible ways of acquiring this knowledge before Christian revelation. This is based on the truth that no known cultural group is bereft of the knowledge of Deity. This according to Barclay (2001) is characteristically:

Paul's approach to those who were completely heathen and without any Jewish background to which he could appeal. With such people he started from nature to get to the God who was behind it all. He started from the here and now to get to the there and then (p. 109).

It is therefore best for us to study and begin any missionary enterprise from those basic religious ideas and experiences of our people than from Christian revelation as wrongly strategized by 
most $15^{\text {th }}$ century missionaries to Africa and their immediate disciples.

2. Paul on the other hand, recognized and taught of the need to emphasise the Unicity and Supremacy of God over and above the various manifestations of Deity. For one, the idea of many Gods appears absurd and defeatist for apart from negating or at least compromising the much cherished benevolence and supremacy of the Supreme Being; such belief in many gods introduces squabbles in the human family.

3. As a matter of fact, Paul did not discard the knowledge or influence of humans and other forces in nature supposed to be mediating between God and Man. He understood that to do this would mean to disregard the people's own religious experiences and needs of the moment. What he rather fought was the belief that these forces could exist independent of God and still retain their roles as God's messengers. Thus when Paul says that they do not have real existence ( see 1Cor. 8:4-6), he means that they exist at least in the consciousness of their believers and influence their behaviours as such, which behaviours should be judged according as to whether they serve the universal human purposes. Thus in 1 Cor. 10: 20,

Paul makes it clear that, although he quite agreed that the heathen gods did not exist, he felt certain that the spirits...did exist and that they were behind the idols and were using them to seduce men from the worship of the true God (Barclay, 2001, p. 75).

4. Pauline approaches seem to suggest the need for a proper categorization of the Deities and their functions. There should be no place for an Unknown God at least (Acts. 17: 23). Here Igbo traditional religion has a lot of work to do in order to set limits for their influences and minimize the confusions therein. The researcher has hinted at the lack of agreement among Igbo scholars and traditionalists alike on the positions of these deities above, and in an earlier work. An adjunct to this is that most traditional practitioners prefer the secrecy of their own deities while claiming their 
superiorities over every other one (which they of course do not know enough). This is rather an arrogant self deception to say the least! The writer hopes that the Igbo should learn from those ancient cultures and civilizations which many people often regard as polytheistic, but who have names for and assign functions to almost all their gods (Greeks for one as indicated by Farnell, 1967, among others).

5. The moral problems also need to be addressed as Paul did. Apart from the call to Christian charity in considering the good of one's weak neighbour, Paul was indeed also concerned that idolatry leads to various forms of immoral passions that imprison their practitioners. In Col. 3: 5 also he clearly considers greed as a form of idolatry. In this case St. Paul appears to be alluding to the almost endless unrests that characterize those communities that pay allegiance to particular deities besides God.

Among the Igbo, the presenter is aware that most disagreements and squabbles among communities are not sustained without the support of their various/ particular deities whose sole aim is to satisfy the needs of their devotees against all odds. Such situations therefore where some try to exonerate the Deities from moral responsibilities should be considered unacceptable since it amounts to unlimited freedom to yet another imperfect creature. Equally so is the presumption that these deities must always act right, which position equates them with the Supreme Being and contradicts the Igbo idea of the Deities as Divine messengers different from the gods of the polytheistic religions as thought by Metuh (1999).

About Angels in Christian theology therefore, McBrien (1994) says that "not every signal from the world of the numinous necessarily bears a message from God. The world of the numinous is as ambiguous and as fraught with sin as is the world of the tangible" (p.256). This should also be applied to Igbo deities in such a way that they also be suspect and subject to judgement. Most cultures (ancient and modern) know and uphold this; the Igbo have no reason to be different.

6. Finally, St. Paul advances that the mediatory roles of the deities are not necessary: God is and remain the creator and sustainer of the 
universe. If this is accepted, then the deities should be considered only to the extent that they advance the perceived provident will of God. Whenever this is suspect therefore, recourse has to be made to the Supreme Being to whom those honours to these Deities are supposed to be directed.

The presenter suggests that such suspicious lights should today be cast especially on the supposed needs for war and violence, and ritual killings in some communities evidently championed by the cults of some of these respected Deities. We observe for instance that there seems to be no reason why some sacrifices to these Deities require human blood when those to God never do. Sacrifices to God appear to use the simplest and cleanest articles, suggesting that God really needs nothing material (Acts.17: 25); why then should his messengers?

\section{Conclusion}

Religious truths concerning the Deities and their influences are so large and inescapable, almost inundating as they are encompassing. These truths are found to be based on the human understanding of the Nature of the Divine, man's needs and the corresponding efforts towards Him; hence the mediatory roles of the Angels, Gods and Lords as St.Paul would classify them (see 1Cor. 8:5). However while it is understandably easier to accept the later, human limitations make it difficult to fully appreciate the former.

But the human mind has for ages been searching through reasoning and especially revelation for credible answers to this Faith problem. Our efforts have hitherto been geared towards ex-raying and solving this question using Pauline reasoning that is so pertinent for the theology and theologians of the $21^{\text {st }}$ century. In all it appears obvious that:

- There is no reason for any total or summary denial of the existence of the Deities which form part and parcel of human religious experiences.

- The task of the theologian or religious scientist is to investigate these religious claims of multifarious peoples and cultures. 
- The moral question appears to be the only determining factor for any acceptable claim to mediatorship.

\section{References}

Anyanwu, H. (1999). African Traditional Religion from the Grassroots. Owerri: Lasen.

Arazu, R. (2005). Our Religion- Past and Present. Awka: Spiritan Centre for Self Realisation

Barclay, W. (2001). The Daily Study Bible. Vols. 7, 8, \& 9. Bangalore: Theological Publications.

Deity. (n.d.). Retrieved September 10, 2009, from Answers.com

Fitzmayer, J. (2000). The letter to the Romans. In R. E. Brown et al (Eds.), The New Jerome Biblical Commentary (pp. 830- 868). London: Geoffery Chapman.

Idols. (n.d.). Retrieved September 10, 2009, from Answers.com

Ifesieh, E. (1989). Religion at the Grassroots: Studies in Igbo Religion. Enugu: Snaap Press.

Madu, J. (1996). Fundamentals of Religious Studies. Calabar: Franedoh Publishers.

McBrien,R. (1994/2000). Catholicism. London: Geoffrey Chapman.

Metuh, I. (1981/1999). God and Man in African Traditional Religion. Enugu: SNAAP

Religions. Onitsha: Imico.

(1987). Comparative Studies of Africa Traditional (1996). Paradigms for Inculculating Christian life in Africa. In Metuh (Ed.) African Inculturation Theology: Africanizing Christianity (pp. 107-127). Onitsha: Imico. 
Murphy-O'Connor, J. (2000). The First Letter to the Corinthians. In R. E. Brown et al. (Eds.), The New Jerome Biblical Commentary (pp. 830-868). London: Geoffery Chapman.

Prat, F. (1964). The Theology of Saint Paul. London. Burn \& Oates.

The Free Dictionary by Farlex (2009). Idols. Retrieved September 11, 2009, from http://www.foldoc.org

The New Jeruasalem Bible. (1985). London: Darton, Longman \& Todd.

Wikipedia, the Free Encyclopedia. (2008, April). Deity. Retrieved September 21, 2009, from http://en.wikipedia.org/wiki/Deity.

Woods, R. (1999). Angels. In J. Komonchak et al. (Ed.). The New Dictionary of Theology (pp.18-19).Bangalore: Theological Publications. 